\title{
OPEN Alcohol consumption, depression, overweight and cortisol levels as determining factors for NR3C1 gene methylation
}

Júlia de Assis Pinheiro ${ }^{1}$, Flávia Vitorino Freitas ${ }^{1,2}{ }^{2}$ Aline Ribeiro Borçoi ${ }^{1}$, Suzanny Oliveira Mendes ${ }^{1}$, Catarine Lima Conti ${ }^{1}$, Juliana Krüger Arpini ${ }^{3}$, Tamires dos Santos Vieira ${ }^{1}$, Rafael Assis de Souza ${ }^{4}$, Dirceu Pereira dos Santos ${ }^{5}$, Wagner Miranda Barbosa ${ }^{2}$, Anderson Barros Archanjo ${ }^{1}$, Mayara Mota de Oliveira ${ }^{1}$, Joaquim Gasparini dos Santos ${ }^{1}$, Bruna Pereira Sorroche ${ }^{6}$, José Claudio Casali-da-Rocha ${ }^{7}$, Leonardo Oliveira Trivilin ${ }^{8}$, Elizeu Batista Borloti ${ }^{9}$, luri Drumond Louro ${ }^{1}$, Lidia Maria Rebolho Batista Arantes ${ }^{6}$ \& Adriana Madeira Alvares-da-Silva ${ }^{1,10,11 \bowtie}$

The NR3C1 glucocorticoid receptor (GR) gene is a component of the stress response system, which can be regulated by epigenetic mechanisms. NR3C1 methylation has been associated with trauma and mental issues, including depression, post-traumatic stress, anxiety, and personality disorders. Previous studies have reported that stressful events are involved in NR3C1 gene methylation, suggesting that its regulation under environmental effects is complex. The present study aimed to analyze associations involving stressors such as socioeconomic status, health conditions, and lifestyle in relation to NR3C1 methylation in adults. This study included 386 individual users of the Brazilian Public Unified Health System (SUS), and evaluated socioeconomic and health conditions, body mass index, cortisol levels, and lifestyle. Data were correlated with NR3C1 methylation, determined using DNA pyrosequencing. The results showed that alcohol consumption, overweight, and high cortisol levels were related to $N R 3 C 1$ demethylation, while depression was related to its methylation. Habits, lifestyle, and health status may influence $N R 3 C 1$ gene regulation via methylation, revealing the complexity of environmental impacts on NR3C1 methylation.

DNA methylation is a widely known mechanism involved in regulating gene expression ${ }^{1}$. It has been recently described as the "modus operandi" of environmental adaptation, and in rapid responses to exposure events, which can be passed on to future generations ${ }^{2}$. Imprinting patterns are inherited and preserved during cell division; however, extrinsic or environmental factors contribute to epigenetic changes during an individual's life ${ }^{3-5}$. Therefore, stressful events can result in the addition or withdrawal of epigenetic marks at specific DNA locations, resulting in altered gene expression ${ }^{6-8}$.

Stress events in humans or animal models have been related to epigenetic changes in specific regulatory regions of the glucocorticoid receptor (GR) gene encoding, which has the function of regulating hypothalamic stress on the neuroendocrine hypothalamic-pituitary-adrenal (HPA) axis, via cortisol production ${ }^{9,10}$. Increased cortisol levels have been previously related to stress and methylation ${ }^{11-13}$. Furthermore, other stressful events or

${ }^{1}$ Biotechnology/Renorbio Graduate Program, Universidade Federal do Espirito Santo, Vitoria, ES, Brazil. '2Department of Pharmacy and Nutrition, Universidade Federal do Espirito Santo, Alegre, ES, Brazil. ${ }^{3}$ Graduate Program in Forest Sciences, Universidade Federal do Espirito Santo, Alegre, ES, Brazil. ${ }^{4}$ Department of Agronomia, Universidade Federal do Espirito Santo, Alegre, ES, Brazil. ${ }^{5}$ Fluminense Federal Institute, Campos dos Goytacazes, RJ, Brazil. ${ }^{6}$ Molecular Oncology Research Center, Hospital do Câncer de Barretos, Barretos, SP, Brazil. ${ }^{7}$ A. C. Camargo Cancer Center, São Paulo, SP, Brazil. ${ }^{8}$ Department of Medicina Veterinária, Universidade Federal do Espirito Santo, Alegre, ES, Brazil. ${ }^{9}$ Department of Social and Developmental Psychology, Universidade Federal do Espírito Santo, Vitoria, ES, Brazil. ${ }^{10}$ Department of Morphology, Health Science Center, Universidade Federal do Espirito Santo, Vitoria, ES, Brazil. ${ }^{11}$ Departamento de Biologia, Universidade Federal do Espirito Santo, Alto Universitário Sem Número, Alegre, ES 29500000, Brazil. ${ }^{\square}$ email: adriana.biomol@gmail.com 
conditions, including trauma ${ }^{14}$, early life stress ${ }^{13,15-17}$, depression ${ }^{10,18,19}$, nutritional alterations ${ }^{20-22}$, psychosocial stress $^{23}$, and consumption of substances such as alcohol and tobacco ${ }^{24,25}$, can alter GR gene encoding methylation levels.

Animal studies have evaluated methylation events directly in the hypothalamus ${ }^{15,26}$, while human studies have evaluated blood methylation events by their homology observed in different tissues with equivalent expression ${ }^{16}$.

The GR belongs to the ligand-dependent nuclear receptor transcription factor superfamily and, in humans, it is encoded by the NR3C1 gene, located on chromosome $5 \mathrm{q} 31-\mathrm{q} 32$, with approximately 140,000 base pairs $^{27-29}$. This gene is composed of 17 exons, eight coding exons (numbered 2-9), and nine non-coding exons, which are located in the gene promoter ${ }^{11,30}$. The NR3C1 promoter region contains multiple methylation-sensitive cytosinephosphate-guanine $(\mathrm{CpG})$ dinucleotide repeats ${ }^{11,31,32}$, among these, the $1 \mathrm{~F}$ region containing $47 \mathrm{CpG}$ sites ${ }^{12,33,34}$.

NR3C1 promoter methylation is responsible for different GR protein levels in various tissues ${ }^{35,36}$, such as the heart, kidney, lung, liver, skin, and especially the hippocampus ${ }^{13,36-42}$. Although it is not expressed in T-cells, it is expressed in B-cells and dendritic cells, homologous to the hippocampus; therefore, it can be evaluated in blood under conditions involving HPA axis changes ${ }^{16,43}$.

NR3C1 promoter methylation may indicate lower mRNA levels and GR expression ${ }^{13,44}$. Thus, even high levels of peripheral cortisol are unable to bind to the cognate receptor to act as an HPA axis negative feedback mechanism, which could result in abnormal responses to stress ${ }^{33,44}$. On the contrary, since stress factors are associated with epigenetic changes, we hypothesized that social and behavioral factors may be associated with NR3C1 gene methylation.

It is still unclear what different conditions might alter $N R 3 C 1$ promoter methylation, especially in broader and multifactorial systems. Thus, the present study aimed to analyze associations involving stressor factors such as socioeconomic status, health conditions, and lifestyle in relation to NR3C1 gene methylation in adult individuals.

\section{Materials and methods}

Patient samples. This was a cross-sectional study carried out with users of the Brazilian Public Unified Health System (SUS) in a southeastern municipality (Alegre-ES), and was conducted between March 2017 and November 2018. The study population was composed of individuals living in urban and rural areas, and was approved by The Ethics Committee in Research with Humans of the Universidade Federal do Espírito Santo Health Sciences Center (CEP/CCS/UFES), under number 1,574,160, dated 6/6/2016. Individuals participating in the study signed written informed consent forms (ICFs). All methods were carried out in accordance with the Ethics Committee of Research with Humans.

Population characteristics. This study was made up of a convenient sample of 386 individuals aged between 20 and 59 years who were users of the Brazilian Primary Health Care Units. Based on individual SUS registration forms, data were collected through individual interviews that evaluated socioeconomic, health, and lifestyle conditions. Low-income was defined as a per capita income/day less than US\$5 (5 American dollars) ${ }^{45}$. Marital status, age, working conditions, and education ( $<8$ years, 8-11 years, and higher education) were also analyzed.

To assess habits and lifestyle features such as alcohol and tobacco consumption, in addition to leisure and physical activity, a structural questionnaire was applied based on the Research Directorate Work Coordination and Income Questionnaire for residents of households from the National Health Survey (NHS) ${ }^{46}$.

In this evaluation, the possible responses to alcohol and tobacco consumption were: (1) currently consuming, (2) used in the past, (3) never used, and for statistical analysis, responses were dichotomized into current consumption: no/yes. In addition, regarding leisure and physical activity, the possible answers for their activity were: (1) weekly, (2) biweekly, (3) monthly, and (4) not performed, dichotomized into yes/no activity.

In the same questionnaire, we addressed self-perceived health status in which the possible answers were: (1) very good, (2) good, (3) regular, (4) bad, (5) very bad, and were dichotomized into: good or very good/regular or poor health for statistical modeling.

Symptoms suggestive of depression were assessed using the Beck Depression Inventory-II (BDI-II) ${ }^{47}$. Values were categorized according to Gomes-Oliveira et al. ${ }^{48}$ considering normal or mild mood disorders (BDI-II $\left.<17\right)$, and symptoms suggestive of depression (BDI-II $\geq 17$ ).

Anthropometric assessment was carried out by qualified professionals using the Food and Nutrition Surveillance System (SISVAN) ${ }^{49}$, which collects information for directing public policies of the Brazilian Unified Health System (SUS). Information such as weight and height were collected, and from the obtained data, body mass index (BMI) was calculated and classified according to the World Health Organization ${ }^{50}$.

Blood analysis. For analysis of cortisol and vitamin D levels and DNA methylation, $10 \mathrm{~mL}$ of peripheral blood was collected from patients by venipuncture after fasting for at least $8 \mathrm{~h}$ as instructed by community health agents (CHA). In a tube containing ethylenediaminetetraacetic acid (EDTA) anticoagulant, $3 \mathrm{~mL}$ of the sample was transferred for molecular analysis, and $2 \mathrm{~mL}$ into a tube containing $\mathrm{NaF}$ (sodium fluoride) anticoagulant for vitamin $\mathrm{D}$ analysis. The remaining blood was transferred to a tube without anticoagulant but containing a separating gel to obtain serum to determine cortisol levels. The tube contents were homogenized by inversion $5-8$ times, and stored in refrigerated coolers over the range of -2 to $8^{\circ} \mathrm{C}$. Blood samples for biochemical evaluation of cortisol and vitamin D levels were transported to Hermes Pardini Laboratory, Belo Horizonte, MG, while samples for DNA extraction were transported to the Biotechnology Laboratory, at the Center for Exact, Natural and Health Sciences, at the Federal University of Espírito Santo (CCENS/UFES).

Cortisol levels and vitamin $\mathrm{D}$ abundance were quantified by chemiluminescence, with reference values for morning cortisol levels of 6.7-22.6 $\mu \mathrm{g} / \mathrm{dL}^{17}$. Results were classified as follows: low cortisol: $<6.7 \mu \mathrm{g} / \mathrm{dL}$; Normal 


\begin{tabular}{|l|l|l|l|l|}
\hline PCR primer & \multicolumn{3}{|l|}{ Conditions } \\
\hline Forward & $5^{\prime}$-TTTTTTTTTTGAAGTTTTTTTA-3 & $95^{\circ} \mathrm{C}$ & $\left(14^{\prime} 30^{\prime \prime}\right)$ & \\
\hline \multirow{5}{*}{ Reverse } & \multirow{5}{*}{$5^{\prime}$-BIOTIN-CCCCCAACTCCCCAAAAA-3' } & $94^{\circ} \mathrm{C}$ & $\left(30^{\prime \prime}\right)$ & \\
\cline { 3 - 5 } & & $50^{\circ} \mathrm{C}$ & $\left(30^{\prime \prime}\right)$ & 45 cycles \\
\cline { 3 - 5 } & $72^{\circ} \mathrm{C}$ & $\left(30^{\prime \prime}\right)$ & $(410 \mathrm{bp})$ \\
\hline & $72^{\circ} \mathrm{C}$ & $\left(10^{\prime}\right)$ & \\
\hline & $4^{\circ} \mathrm{C}$ & Indefinitely & \\
\hline Sequencing primers & & & \\
\hline 40 to 42 CpG & $5^{\prime}$-AGAAAAGAAATTGGAGAAATT-3' \\
\hline 43 to 47 CpG & $5^{\prime}$-GTTTTAGAGAGATTAGGT-3' \\
\hline Analyzed sequences & YGGTGGTTTTTTTAAYGTYGTTTTAATCGTGTTGATCAGTCGCTTA \\
\hline Seq 1 & YGGTTTTYGTYGTTGTYGTYGTTAGTCAGTTCAGTCGTAGTCAGTCGTA \\
\hline Seq 2 &
\end{tabular}

Table 1. PCR and Pyrosequencing primers and conditions.

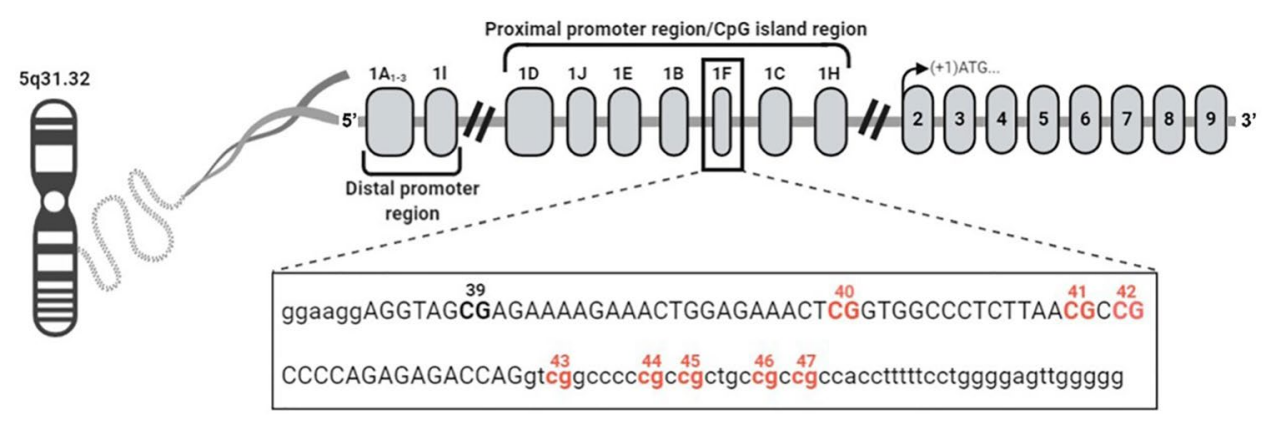

Figure 1. Promoter region of NR3C1 examined within this study. The CpGs studied (40-47) are represented in red and are also numbered. Lowercase nucleotides represent intronic regions, while uppercase nucleotides represent exon 1F. GenBank (NCBI-Access number: AY436590.1).

CORTISOL: 6.7-22.6 $\mu \mathrm{g} / \mathrm{dL}$; high cortisol: serum levels $>22.6 \mu \mathrm{g} / \mathrm{dL}$. At the data analysis stage, the variable was dichotomized into high cortisol $(\geq 6.7 \mu \mathrm{g} / \mathrm{dL})$ and not high cortisol $(<6.7 \mu \mathrm{g} / \mathrm{dL})$. Vitamin D levels were classified as deficiency: $<20 \mathrm{ng} / \mathrm{mL}$, insufficiency: $20-29 \mathrm{ng} / \mathrm{mL}$, and sufficiency: $\geq 30 \mathrm{ng} / \mathrm{mL}$, and for statistical evaluation, these scores were dichotomized into insufficiency: $<30 \mathrm{ng} / \mathrm{mL}$, and sufficiency: $\geq 30 \mathrm{ng} / \mathrm{mL}^{20,51}$.

DNA extraction was performed as described by Salazar et al. ${ }^{52}$. A NanoDrop 2000/2000c Spectrophotometer was used to verify DNA quality and concentration for further NR3C1 methylation analysis.

Quantitative pyrosequencing methylation assay. Of all samples with good DNA quality and concentration, a subsample of 285 patients was randomly assigned to undergo pyrosequencing methylation assays.

Sodium-bisulfite conversion of $1 \mu \mathrm{g}$ of DNA was performed using the EpiTect Bisulfite Kit (Qiagen, Valencia, CA, USA), following the manufacturer's recommendations. Pyrosequencing methylation assays were performed as previously described ${ }^{53,54}$.

PCR product quality was checked on $2 \%$ agarose gels using GelRed (Uniscience). Pyrosequencing was performed using a PSQ 96 ID Pyrosequencer (Qiagen, Valencia, CA, USA) with PyroMark Gold Q96 Reagent Kit (Qiagen), according to the manufacturer's protocol. All pyrosequencing conditions are listed in Table 1.

A single pyrosequencing reaction was performed for each individual, and the reaction was evaluated for quality. The percentage of methylation was recorded for each CpG from 40 to 47, individually and on average, evaluated in PyroMark Q96 ID Software 2.5 version 2.5.10.7, using default software settings. In this study, we considered all methylation levels detected in pyrosequencing to classify individuals as methylated or unmethylated, when they presented methylation at any percentage above zero.

A representative scheme of the amplified $1 \mathrm{~F}$ region of $N R 3 C 1$ and the eight $\mathrm{CpGs}$ site-specific analyzed using bisulfite-pyrosequencing assays are shown in Fig. 1.

Statistical analysis. Data were analyzed using Chi-squared tests in a $2 \times 2$ contingency table and a statistical significance level of 5\%. Quantitative data are expressed as median and interquartile ranges.

Results of quantitative analysis of NR3C1 gene methylation did not follow a normal distribution, even after exponential conversion. In this manner, the methylation data were dichotomized. The mean methylation values of CGs segment from 40 to 47 were calculated for qualitative analysis such that values $>0$ were categorized as methylated, and values equal to 0 were categorized as unmethylated. Then, applied bivariate analyses were performed 
using Poisson regression models with robust variance, with the dependent variable being methylation of the segment, and as explanatory variables socioeconomic aspects, health, and lifestyle, as well as suggestive symptoms of depression. After data characterization, independent variables were recategorized dichotomously according to the classifications in normal state/altered states before being included in the multivariate study model.

Predictive variables that achieved $p$ values lower than $0.20(\mathrm{p}<0.20)$ were inserted into the multivariate Poisson regression model with robust variance. The backward method was used, and those variables with less significance (greater $\mathrm{p}$ value) were removed one by one from the model. The procedure was repeated until all variables present in the model were statistically significant $(\mathrm{p}<0.05)$. The Hosmer-Lemeshow test was used to verify the fit of the final model. The prevalence ratio (PR) with $95 \%$ confidence interval (95\% CI) was used as an effect measure. For all analyses, a significance level of $5 \%$ was adopted. Statistical analyses were performed using SPSS software (v.13.0 for Windows) and Stata v.11.0.

\section{Results}

Socioeconomic profile. Our results were obtained from a total of 285 individuals evaluated by pyrosequencing of the NR3C1 1F region; 198 individuals did not show any percentage of methylation detected, whereas 87 exhibited measurable percentages of methylation. The median methylation level was $0.0(0.0-12.9 \%)$. Table 2 presents a population description, which was divided into unmethylated and methylated. Individuals were predominantly female (80.6\%), 75\% lived with a partner, and the median age was 42.5 (33.7-52.0) years. Most of them had $<8$ years of formal education $(46.4 \%)$, low income $(70.2 \%)$, did not drink, smoke, or perform physical or leisure activities.

Methylation analysis of NR3C1. The average methylation index was calculated from CpG sites methylation percentages. These percentages were dichotomized into unmethylated ( $0 \%$ methylation) and methylated (values $>0 \%$ methylated).

Bivariate Poisson regression showed associations between methylation profiles and gender $(\mathrm{p}=0.047)$, alcohol consumption $(p<0.001)$, depression $(p=0.022)$, body index $(p=0.017)$, and cortisol levels $(p<0.001)$ (Table 3$)$.

From variables in the Bivariate Poisson regression with values $\mathrm{p}<0.20$, the multivariate model was designed. The results showed that methylation is associated with alcohol consumption, depression, BMI, and high cortisol levels (Table 4).

As observed in Table 4, alcohol consumption was associated to $70 \%$ decrease in the prevalence of methylation $(1-0.30 \times 100)$; being overweight showed a $34 \%$ lower prevalence of methylation than not being overweight (1-0.66 $\times 100)$, and high cortisol was associated with a lower prevalence of methylation, however with a measure of low effect $\mathrm{PR}=0.09^{-5}$. In contrast, depression exhibited the opposite effect, being directly related to methylation with prevalence of 55\% higher than non-depressed individuals ( 1.55 times more prevalent).

The final model was statistically significant $(p<0.001)$, presenting a pseudo $r^{2}=0.0759$ and, after adjustment by Hosmer and Lemeshow, showed good adherence $(\mathrm{p}=0.99)$.

\section{Discussion}

This study presents individuals with low income, low education, and predominantly of female gender. Our goal was to establish a broader assessment of factors related to NR3C1 gene methylation, such as socioeconomic aspects, health, and lifestyle.

We have shown that alcohol consumption, overweight, and high cortisol levels are related to NR3C1 nonmethylation, while depression is related to its methylation. Argentieri et al. ${ }^{16}$ presented a series of studies that related hyper- or hypomethylation with specific CpG methylation of this gene.

Few studies have evaluated the relationship between methylation patterns and alcohol consumption. It was expected that alcohol as a stressor factor could stimulate the HPA axis by increasing cortisol levels and NR3C1 methylation. Gatta et al. ${ }^{24}$ reported hypermethylation of $N R 3 C 1$ exon $1 \mathrm{H}$ in the prefrontal cortex of individuals with alcohol abuse disorders compared with that in a control group. However, our data showed low levels of NR3C1 1F region methylation. Corroborating our findings, Dogan et al. ${ }^{25}$ showed a relationship between alcohol consumption and decreased levels of NR3C1 methylation in a 64-patient cohort.

Studies have demonstrated that alcohol consumption may lead to HPA axis alterations, with glucocorticoid release modifications ${ }^{55,56}$. Here, we showed association between alcohol consumption and NR3C1 methylation, which indicated that alcohol-mediated modulation of the HPA axis may occur through epigenetic changes.

Although self-reporting of alcohol consumption was insufficient to control its effects on NR3C1 methylation, our finding is relevant because alcohol represents a large fraction of the drugs consumed by the world population, and the epigenetic effects induced by its consumption are still little known.

Our analysis showed an association between suggestive symptoms of depression, as evaluated by Beck scores $\geq 17$, with increased methylation at NR3C1 40-47 1F CpGs sites. Other authors have associated methylation alterations in the $1 \mathrm{~F}$ region CpG 36-39 sites with depressive status in adolescents ${ }^{57}$ and in CpGs 36-44 on maternal exposure to gestational stress and depression in children ${ }^{58}$.

In addition, other authors have studied the $1 \mathrm{~F}$ region, showing hypomethylation involving CpGs 35-47, with hypomethylation specifically of CpG 43 associated with depression ${ }^{59}$. There are also studies addressing the $1 \mathrm{~F}$ region showing hypomethylation of CpGs 35-39 in individuals with depression ${ }^{19}$. However, the present study provides new information that individuals with depressive symptoms, and frequent use of the public health system, exhibit methylation of the NR3C1 $1 \mathrm{~F}$ region.

In this manner, it is possible that NR3C1 methylation is associated with depression, in that NR3C1 gene methylation may indicate lower mRNA levels and GR expression, leading to imbalanced HPA axis modulation, which could result in abnormal responses to stress, and increase susceptibility to depression ${ }^{33,44}$. 


\begin{tabular}{|c|c|c|c|c|c|c|c|}
\hline \multirow[b]{3}{*}{ Characteristic } & \multirow{2}{*}{\multicolumn{2}{|c|}{ Total }} & \multicolumn{4}{|c|}{ Methylation } & \multirow[b]{3}{*}{$p$} \\
\hline & & & \multicolumn{2}{|l|}{ No } & \multicolumn{2}{|c|}{ Yes } & \\
\hline & $\mathbf{N}$ & $(\%)$ & $\mathbf{N}$ & $(\%)$ & $\mathbf{N}$ & $(\%)$ & \\
\hline \multicolumn{8}{|l|}{ Gender } \\
\hline Male & 60 & 21.0 & 50 & 17.5 & 10 & 3.5 & $0.009^{*}$ \\
\hline Female & 225 & 79.0 & 148 & 52.0 & 77 & 27.0 & \\
\hline \multicolumn{8}{|l|}{ Age (years) } \\
\hline $20-40$ & 125 & 43.8 & 87 & 30.5 & 38 & 13.3 & 0.967 \\
\hline $41-60$ & 160 & 56.2 & 111 & 39.0 & 49 & 17.2 & \\
\hline \multicolumn{8}{|l|}{ Marital status } \\
\hline Single & 70 & 24.6 & 55 & 19.3 & 15 & 5.3 & 0.057 \\
\hline No single & 215 & 75.4 & 143 & 50.2 & 72 & 25.2 & \\
\hline \multicolumn{8}{|l|}{ Education } \\
\hline Basic education & 240 & 84.2 & 167 & 58.6 & 73 & 25.6 & 0.926 \\
\hline Higher education & 45 & 15.8 & 31 & 10.9 & 14 & 4.9 & \\
\hline \multicolumn{8}{|l|}{ Working } \\
\hline Yes & 151 & 53.0 & 103 & 36.2 & 48 & 16.8 & 0.623 \\
\hline No & 134 & 47.0 & 95 & 33.3 & 39 & 13.7 & \\
\hline \multicolumn{8}{|l|}{ Income } \\
\hline Non-low income ( $\geq \$ 5.00 /$ day) & 81 & 28.4 & 58 & 20.4 & 23 & 8.0 & 0.623 \\
\hline Low income $(<\$ 5.00 /$ day $)$ & 204 & 71.6 & 140 & 49.1 & 64 & 22.5 & \\
\hline \multicolumn{8}{|l|}{ Tobacco consumption } \\
\hline No & 261 & 91.6 & 176 & 61.8 & 85 & 29.8 & $0.014^{\star}$ \\
\hline Yes & 24 & 8.4 & 22 & 7.7 & 2 & 0.7 & \\
\hline \multicolumn{8}{|l|}{ Alcohol consumption } \\
\hline No & 201 & 70.2 & 125 & 43.9 & 75 & 26.3 & $0.000^{*}$ \\
\hline Yes & 84 & 29.8 & 73 & 25.6 & 12 & 4.2 & \\
\hline \multicolumn{8}{|l|}{ Weekly drinking } \\
\hline$<7$ drinks & 64 & 76.2 & 53 & 63.1 & 11 & 13.1 & 0.438 \\
\hline$>7$ drinks & 20 & 23.8 & 18 & 21.4 & 2 & 2.4 & \\
\hline \multicolumn{8}{|l|}{ Physical activity } \\
\hline Yes & 95 & 33.3 & 69 & 24.2 & 26 & 9.1 & 0.413 \\
\hline No & 190 & 66.7 & 129 & 45.3 & 61 & 21.4 & \\
\hline \multicolumn{8}{|l|}{ Leisure activity } \\
\hline Yes & 132 & 46.3 & 97 & 34.1 & 35 & 12.3 & 0.172 \\
\hline No & 253 & 53.7 & 101 & 35.4 & 52 & 18.2 & \\
\hline \multicolumn{8}{|l|}{ Self-rated health } \\
\hline Good or very good & 145 & 50.9 & 105 & 36.8 & 40 & 14.0 & 0.273 \\
\hline Regular or poor & 140 & 49.1 & 93 & 32.6 & 47 & 16.5 & \\
\hline Depression & & & & & & & \\
\hline BDI-II $<17$ & 194 & 68.1 & 136 & 51.3 & 58 & 21.9 & 0.142 \\
\hline BDI-II $\geq 17$ & 71 & 24.9 & 43 & 16.2 & 28 & 10.6 & \\
\hline Not available $^{\#}$ & 20 & 7.0 & & & & & \\
\hline Body mass index-BMI & & & & & & & \\
\hline No overweight & 96 & 33.7 & 59 & 20.7 & 37 & 13.0 & $0.036^{*}$ \\
\hline Overweight & 189 & 66.3 & 139 & 48.8 & 50 & 17.5 & \\
\hline Vitamin D & & & & & & & \\
\hline Sufficiency & 264 & 92.6 & 185 & 64.9 & 79 & 27.7 & 0.434 \\
\hline Deficiency & 21 & 7.4 & 13 & 4.6 & 8 & 2.8 & \\
\hline High cortisol levels & & & & & & & \\
\hline No & 270 & 94.7 & 185 & 67.0 & 85 & 30.8 & 0.107 \\
\hline Yes & 6 & 2.1 & 6 & 2.2 & 0 & 0.0 & \\
\hline Not available $^{\#}$ & 9 & 3.2 & & & & & \\
\hline Total & 285 & 100.00 & 198 & 69.50 & 87 & 30.50 & \\
\hline
\end{tabular}

Table 2. Sample characteristics according to methylation of $1 \mathrm{~F}$ region NR3C1 gene. BDI-II Beck Depression Inventory-II, BFIS Brazilian Food Insecurity Scale, FNS Food and Nutrition Security, FNiS Food and Nutrition Insecurity, BMI Body Mass Index. "Not available (not considered in the statistical calculations). Categorical variables presented in relative (\%) and absolute (n) frequencies. Quantitative variables presented in medians and interquartile ranges (IR), according to normality (Kolmogorov-Smirnov test); ${ }^{\star} \mathrm{p}$ value: Mann-Whitney U or chi-square, at $5 \%$ significance $(\mathrm{p}<0.05)$. 


\begin{tabular}{|c|c|c|c|}
\hline \multirow[b]{3}{*}{ Characteristics } & \multicolumn{3}{|c|}{ Methylation } \\
\hline & \multicolumn{3}{|c|}{ (CpG 40-47) } \\
\hline & PR & 95\% CI & $\mathbf{p}$ \\
\hline \multicolumn{4}{|l|}{ Gender } \\
\hline Male & 1.8 & \begin{tabular}{|l|}
$1.00-3.41$ \\
\end{tabular} & 0.047 \\
\hline \multicolumn{4}{|l|}{ Female } \\
\hline \multicolumn{4}{|l|}{ Age (years) } \\
\hline $20-40$ & 1.0 & \begin{tabular}{|l|}
$0.70-1.47$ \\
\end{tabular} & 0.938 \\
\hline \multicolumn{4}{|l|}{$41-60$} \\
\hline \multicolumn{4}{|l|}{ Marital status } \\
\hline Single & 1.6 & $0.95-2.63$ & 0.073 \\
\hline \multicolumn{4}{|l|}{ Not single } \\
\hline \multicolumn{4}{|l|}{ Education } \\
\hline Basic education & 0.9 & $0.55-1.54$ & 0.779 \\
\hline \multicolumn{4}{|l|}{ Higher education } \\
\hline \multicolumn{4}{|l|}{ Working } \\
\hline Yes & 0.9 & $0.67-1.43$ & 0.785 \\
\hline \multicolumn{4}{|l|}{ No } \\
\hline \multicolumn{4}{|l|}{ Income } \\
\hline Non-low income ( $\geq \$ 5.00 /$ day $)$ & 1.2 & \begin{tabular}{|l|}
$0.77-1.80$ \\
\end{tabular} & 0.443 \\
\hline \multicolumn{4}{|l|}{ Low income $(<\$ 5.00 /$ day $)$} \\
\hline \multicolumn{4}{|l|}{ Tobacco consumption } \\
\hline No & 0.2 & $0.69-1.04$ & 0.058 \\
\hline \multicolumn{4}{|l|}{ Yes } \\
\hline \multicolumn{4}{|l|}{ Alcohol consumption } \\
\hline No & 0.3 & $0.16-0.53$ & $<0.001$ \\
\hline \multicolumn{4}{|l|}{ Yes } \\
\hline \multicolumn{4}{|l|}{ Physical activity } \\
\hline Yes & 1.1 & $0.76-1.72$ & 0.500 \\
\hline \multicolumn{4}{|l|}{ No } \\
\hline \multicolumn{4}{|l|}{ Leisure activity } \\
\hline Yes & 1.2 & \begin{tabular}{|l|}
$0.87-1.87$ \\
\end{tabular} & 0.196 \\
\hline \multicolumn{4}{|l|}{ No } \\
\hline Self-rated health & & & \\
\hline Good or very good & 1.3 & \begin{tabular}{|l|}
$0.90-1.91$ \\
\end{tabular} & 0.147 \\
\hline Regular or poor & & & \\
\hline Depression & & & \\
\hline BDI-II $<17$ & 1.5 & $1.06-2.27$ & 0.022 \\
\hline BDI-II $\geq 17$ & & & \\
\hline Body mass index-BMI & & & \\
\hline Not overweight & 0.6 & \begin{tabular}{|l|}
$0.44-0.92$ \\
\end{tabular} & 0.017 \\
\hline Overweight & & & \\
\hline Vitamin D & & & \\
\hline Sufficiency & 1.2 & \begin{tabular}{|l|}
$0.69-2.40$ \\
\end{tabular} & 0.413 \\
\hline Deficiency & & & \\
\hline High cortisol levels & & & \\
\hline No & $2.2^{-9}$ & $1.11^{-9}-4.65^{-9}$ & $<0.001$ \\
\hline Yes & & & \\
\hline
\end{tabular}

Table 3. Bivariate Poisson regression analysis with robust variance for NR3C1 $1 \mathrm{~F}$ region methylation. Bold values indicate significance result. $P R$ prevalence ratio, $95 \% C I$ confidence interval, $p$ p value.

Furthermore, high cortisol levels were associated with non-methylation, but with a very low prevalence ratio (Table 4). High levels of cortisol have already been related to NR3C1 gene methylation in maternal and postnatal gestational exposure to childhood stress ${ }^{14,33,60}$.In our study, only 8 individuals presented high cortisol levels, while the others had normal or low levels, but which may not be representative.

On the contrary, multivariate analysis of risk factors showed that being overweight is associated with non-methylation, with a prevalence ratio of 0.67 , indicating that being overweight reduces the prevalence of 


\begin{tabular}{|c|c|c|c|}
\hline \multirow[b]{3}{*}{ Characteristic } & \multicolumn{3}{|c|}{ Methylation } \\
\hline & \multicolumn{3}{|c|}{ (CpG 40-47) } \\
\hline & PR & $95 \% \mathrm{CI}$ & $\mathbf{p}$ \\
\hline \multicolumn{4}{|c|}{ Alcohol consumption } \\
\hline \multicolumn{4}{|l|}{ No } \\
\hline Yes & 0.30 & $0.16-053$ & $<0.001$ \\
\hline \multicolumn{4}{|l|}{ Depression } \\
\hline \multicolumn{4}{|l|}{ BDI-II $<17$} \\
\hline BDI-II $\geq 17$ & 1.55 & $1.07-2.24$ & 0.018 \\
\hline \multicolumn{4}{|c|}{ Body mass index-BMI } \\
\hline \multicolumn{4}{|l|}{ Not overweight } \\
\hline Overweight & 0.66 & $0.46-0.95$ & 0.017 \\
\hline \multicolumn{4}{|c|}{ High cortisol levels } \\
\hline \multicolumn{4}{|l|}{ No } \\
\hline Yes & $0.09^{-5}$ & $3.8^{-7}-1.9^{-6}$ & $<0.001$ \\
\hline
\end{tabular}

Table 4. Multivariate Poisson regression analysis with robust variance for methylation of NR3C1 1F region. Bold values indicate significance result. $P R$ prevalence ratio, 95\% CI confidence interval, $p \mathrm{p}$ value.

methylation by $33 \%$. Chronic stress has previously been related to increased cortisol levels, leading to weight gain $^{61}$. Excess weight is also related to chronic inflammation through NFkB pathways; however, no association between overweight and methylation status has been previously reported for the $N R 3 C 1$ gene ${ }^{62}$. It is possible that hypomethylation of this region may be related to low-grade inflammation, a feature of the overweight state ${ }^{63}$.

Although it was a cross-sectional study, and it is not possible to establish any causal relationships, this study is relevant as it revealed a direct or inverse association between methylation, alcohol consumption, overweight, and high cortisol levels related to NR3C1 non-methylation, whereas depression was related to methylation.

Thus, we suggest that habits, lifestyle, and health status may influence $N R 3 C 1$ gene regulation via methylation. Relationships involving genotype, environment, and phenotypic outcomes may be more refined than previously thought, depending on specific stressful events that can result in unique clinical consequences.

Received: 1 June 2020; Accepted: 9 March 2021

Published online: 24 March 2021

\section{References}

1. Chen, D., Meng, L., Pei, F., Zheng, Y. \& Leng, J. A review of DNA methylation in depression. J. Clin. Neurosci. 43, 39-46. https:// doi.org/10.1016/j.jocn.2017.05.022 (2017).

2. Vidaki, A., Daniel, B. \& Court, D. S. Forensic DNA methylation profiling-potential opportunities and challenges. Forensic Sci. Int. Genet. 7, 499-507. https://doi.org/10.1016/j.fsigen.2013.05.004 (2013).

3. Kader, F. \& Ghai, M. DNA methylation-based variation between human populations. Mol. Genet. Genom. 292, 5-35. https://doi. org/10.1007/s00438-016-1264-2 (2017)

4. Kader, F., Ghai, M. \& Maharaj, L. The effects of DNA methylation on human psychology. Behav. Brain Res. 346, 47-65. https://doi. org/10.1016/j.bbr.2017.12.004 (2018).

5. Lacal, I. \& Ventura, R. Epigenetic inheritance: Concepts, mechanisms and perspectives. Front. Mol. Neurosci. 11, 292. https://doi. org/10.3389/fnmol.2018.00292 (2018).

6. Moore, L. D., Le, T. \& Fan, G. DNA methylation and its basic function. Neuropsychopharmacology 38, 23-38. https://doi.org/10. 1038/npp.2012.112 (2013).

7. Yang, X. et al. Gene body methylation can alter gene expression and is a therapeutic target in cancer. Cancer Cell 26, 577-590. https://doi.org/10.1016/j.ccr.2014.07.028 (2014).

8. Keller, T. E., Han, P. \& Yi, S. V. Evolutionary transition of promoter and gene body DNA methylation across invertebrate-vertebrate boundary. Mol. Biol. Evol. 33, 1019-1028. https://doi.org/10.1093/molbev/msv345 (2016).

9. Weaver, I. C. et al. Epigenetic programming by maternal behavior. Nat. Neurosci. 7, 847-854. https://doi.org/10.1038/nn1276 (2004).

10. Nantharat, M., Wanitchanon, T., Amesbutr, M., Tammachote, R. \& Praphanphoj, V. Glucocorticoid receptor gene (NR3C1) promoter is hypermethylated in Thai females with major depressive disorder. Genet. Mol. Res. 14, 19071-19079. https://doi.org/10. 4238/2015.December.29.15 (2015).

11. Palma-Gudiel, H., Cordova-Palomera, A., Leza, J. C. \& Fananas, L. Glucocorticoid receptor gene (NR3C1) methylation processes as mediators of early adversity in stress-related disorders causality: A critical review. Neurosci. Biobehav. Rev. 55, 520-535. https:// doi.org/10.1016/j.neubiorev.2015.05.016 (2015).

12. Radtke, K. M. et al. Transgenerational impact of intimate partner violence on methylation in the promoter of the glucocorticoid receptor. Transl. Psychiatry 1, e21. https://doi.org/10.1038/tp.2011.21 (2011).

13. McGowan, P. O. et al. Epigenetic regulation of the glucocorticoid receptor in human brain associates with childhood abuse. Nat. Neurosci. 12, 342-348. https://doi.org/10.1038/nn.2270 (2009).

14. Yehuda, R. et al. Lower methylation of glucocorticoid receptor gene promoter $1 \mathrm{~F}$ in peripheral blood of veterans with posttraumatic stress disorder. Biol. Psychiatr. 77, 356-364. https://doi.org/10.1016/j.biopsych.2014.02.006 (2015).

15. McGowan, P. O. et al. Broad epigenetic signature of maternal care in the brain of adult rats. PLoS One 6, e14739. https://doi.org/ 10.1371/journal.pone.0014739 (2011).

16. Argentieri, M. A., Nagarajan, S., Seddighzadeh, B., Baccarelli, A. A. \& Shields, A. E. Epigenetic pathways in human disease: The impact of DNA methylation on stress-related pathogenesis and current challenges in biomarker development. EBioMedicine 18, 327-350. https://doi.org/10.1016/j.ebiom.2017.03.044 (2017). 
17. Silva, B. C. et al. Subclinical Cushing's disease: Presentation of three cases and critical review. Arq. Bras. Endocrinol. Metabol. 51, 625-630. https://doi.org/10.1590/s0004-27302007000400018 (2007).

18. Borçoi, A. R. et al. Risk factors for depression in adults: NR3C1 DNA methylation and lifestyle association. J. Psychiatr. Res. 16(121), 24-30. https://doi.org/10.1016/j.jpsychires.2019.10.011 (2020).

19. Na, K. S. et al. Association between glucocorticoid receptor methylation and hippocampal subfields in major depressive disorder. PLoS One 9, e85425. https://doi.org/10.1371/journal.pone.0085425 (2014).

20. Holick, M. F. et al. Evaluation, treatment, and prevention of vitamin D deficiency: An Endocrine Society clinical practice guideline. J. Clin. Endocrinol. Metab. 96, 1911-1930. https://doi.org/10.1210/jc.2011-0385 (2011).

21. Amenyah, S. D. et al. Influence of nutrients involved in one-carbon metabolism on DNA methylation in adults-a systematic review and meta-analysis. Nutr. Rev. https://doi.org/10.1093/nutrit/nuz094 (2020).

22. Zhang, N. Epigenetic modulation of DNA methylation by nutrition and its mechanisms in animals. Anim. Nutr. 1, 144-151. https:// doi.org/10.1016/j.aninu.2015.09.002 (2015).

23. Uddin, M., Jansen, S. \& Telzer, E. H. Adolescent depression linked to socioeconomic status? Molecular approaches for revealing premorbid risk factors. BioEssays 39(3), 1600194. https://doi.org/10.1002/bies.201600194 (2017).

24. Gatta, E. et al. Genome-wide methylation in alcohol use disorder subjects: Implications for an epigenetic regulation of the corticolimbic glucocorticoid receptors (NR3C1) [published online ahead of print, 2019 Jun 25]. Mol. Psychiatry https://doi.org/10.1038/ s41380-019-0449-6 (2019).

25. Dogan, M. V., Lei, M. K., Beach, S. R., Brody, G. H. \& Philibert, R. A. Alcohol and tobacco consumption alter hypothalamic pituitary adrenal axis DNA methylation. Psychoneuroendocrinology 66, 176-184. https://doi.org/10.1016/j.psyneuen.2016.01.018 (2016).

26. Alt, S. R. et al. Differential expression of glucocorticoid receptor transcripts in major depressive disorder is not epigenetically programmed. Psychoneuroendocrinology 35, 544-556. https://doi.org/10.1016/j.psyneuen.2009.09.001 (2010).

27. Oakley, R. H. \& Cidlowski, J. A. The biology of the glucocorticoid receptor: New signaling mechanisms in health and disease. J. Allergy Clin. Immunol. 132, 1033-1044. https://doi.org/10.1016/j.jaci.2013.09.007 (2013).

28. Steiger, H., Labonte, B., Groleau, P., Turecki, G. \& Israel, M. Methylation of the glucocorticoid receptor gene promoter in bulimic women: Associations with borderline personality disorder, suicidality, and exposure to childhood abuse. Int. J. Eat. Disord. 46, 246-255. https://doi.org/10.1002/eat.22113 (2013).

29. Turner, J. D., Vernocchi, S., Schmitz, S. \& Muller, C. P. Role of the 5'-untranslated regions in post-transcriptional regulation of the human glucocorticoid receptor. Biochem. Biophys. Acta. 1051-1061, 2014. https://doi.org/10.1016/j.bbagrm.2014.08.010 (1839).

30. Daskalakis, N. P. \& Yehuda, R. Site-specific methylation changes in the glucocorticoid receptor exon $1 \mathrm{~F}$ promoter in relation to life adversity: Systematic review of contributing factors. Front. Neurosci. 8, 369. https://doi.org/10.3389/fnins.2014.00369 (2014).

31. Brenet, F. et al. DNA methylation of the first exon is tightly linked to transcriptional silencing. PLoS One 6, e14524. https://doi. org/10.1371/journal.pone.0014524 (2011).

32. Provencal, N. \& Binder, E. B. The effects of early life stress on the epigenome: From the womb to adulthood and even before. Exp. Neurol. 268, 10-20. https://doi.org/10.1016/j.expneurol.2014.09.001 (2015).

33. Oberlander, T. F. et al. Prenatal exposure to maternal depression, neonatal methylation of human glucocorticoid receptor gene (NR3C1) and infant cortisol stress responses. Epigenetics 3, 97-106. https://doi.org/10.4161/epi.3.2.6034 (2008).

34. Murgatroyd, C., Quinn, J. P., Sharp, H. M., Pickles, A. \& Hill, J. Effects of prenatal and postnatal depression, and maternal stroking, at the glucocorticoid receptor gene. Transl. Psychiatry 5, e560. https://doi.org/10.1038/tp.2014.140 (2015).

35. Presul, E., Schmidt, S., Kofler, R. \& Helmberg, A. Identification, tissue expression, and glucocorticoid responsiveness of alternative first exons of the human glucocorticoid receptor. J. Mol. Endocrinol. 38, 79-90. https://doi.org/10.1677/jme.1.02183 (2007).

36. Yan, K. et al. Subcellular localization of glucocorticoid receptor protein in the human kidney glomerulus. Kidney Int. 56, 65-73. https://doi.org/10.1046/j.1523-1755.1999.00503.x (1999).

37. Ito, K., Getting, S. J. \& Charron, C. E. Mode of glucocorticoid actions in airway disease. Sci. World J. 6, 1750-1769. https://doi.org/ $10.1100 /$ tsw.2006.274 (2006)

38. Chebotaev, D., Yemelyanov, A. \& Budunova, I. The mechanisms of tumor suppressor effect of glucocorticoid receptor in skin. Mol. Carcinog. 46, 732-740. https://doi.org/10.1002/mc.20349 (2007).

39. Mueller, K. M. et al. Hepatic growth hormone and glucocorticoid receptor signaling in body growth, steatosis and metabolic liver cancer development. Mol. Cell. Endocrinol. 361, 1-11. https://doi.org/10.1016/j.mce.2012.03.026 (2012).

40. Panagiotou, C., Mihailidou, C., Brauhli, G., Katsarou, O. \& Moutsatsou, P. Effect of steviol, steviol glycosides and stevia extract on glucocorticoid receptor signaling in normal and cancer blood cells. Mol. Cell. Endocrinol. 460, 189-199. https://doi.org/10.1016/j. mce.2017.07.023 (2018).

41. Richardson, R. V. et al. Glucocorticoid receptor alters isovolumetric contraction and restrains cardiac fibrosis. J. Endocrinol. 232, 437-450. https://doi.org/10.1530/JOE-16-0458 (2017).

42. Wang, W. et al. Increased methylation of glucocorticoid receptor gene promoter $1 \mathrm{~F}$ in peripheral blood of patients with generalized anxiety disorder. J. Psychiatr. Res. 91, 18-25. https://doi.org/10.1016/j.jpsychires.2017.01.019 (2017).

43. Turner, J. D. \& Muller, C. P. Structure of the glucocorticoid receptor (NR3C1) gene 5' untranslated region: Identification, and tissue distribution of multiple new human exon 1. J. Mol. Endocrinol. 35, 283-292. https://doi.org/10.1677/jme.1.01822 (2005).

44. Perroud, N. et al. Childhood maltreatment and methylation of the glucocorticoid receptor gene NR3C1 in bipolar disorder. Br. J. Psychiatry 204, 30-35. https://doi.org/10.1192/bjp.bp.112.120055 (2014).

45. Neri M. C. FGV/IBRE, CPS A Nova Classe Média. ed. CPS FGV/IBRE. Editora Fundação Getúlio Vargas, Rio de Janeiro. 70 (2008).

46. Instituto Brasileiro de Geografia e Estatística. Pesquisa Nacional de Saúde 2013: Percepção do estado de saúde, estilos de vida e doenças crônicas. Rio de Janeiro: Instituto Brasileiro de Geografia e Estatística; 2014. https://www.pns.icict.fiocruz.br/index.php? pag=proposicao.

47. Jackson-Koku, G. Beck Depression Inventory. Occup. Med. 66, 174-175. https://doi.org/10.1093/occmed/kqv087 (2016).

48. Gomes-Oliveira, M. H., Gorenstein, C., Lotufo Neto, F., Andrade, L. H. \& Wang, Y. P. Validation of the Brazilian Portuguese version of the Beck Depression Inventory-II in a community sample. Rev. Bras. Psiquiatr. 34, 389-394. https://doi.org/10.1016/j.rbp. 2012.03.005 (2012).

49. Ministério da Saude, S. Orientações para a coleta e análise de dados antropométricos em serviços de saúde : Norma Técnica do Sistema de Vigilância Alimentar e Nutricional. Secretaria de Atenção à Saúde Departamento de atenção Básica de 2011 (2011).

50. WHO, W. H. O. Institutes Health of National 1, 1-22 (2017).

51. Holick, M. F. Vitamin D deficiency. N. Engl. J. Med. 357, 266-281. https://doi.org/10.1056/NEJMra070553 (2007).

52. Salazar, L. A., Hirata, M. H., Cavalli, S. A., Machado, M. O. \& Hirata, R. D. Optimized procedure for DNA isolation from fresh and cryopreserved clotted human blood useful in clinical molecular testing. Clin. Chem. 44, 1748-1750 (1998).

53. Colella, S., Shen, L., Baggerly, K. A., Issa, J. P. \& Krahe, R. Sensitive and quantitative universal pyrosequencing methylation analysis of CpG sites. Biotechniques 35, 146-150. https://doi.org/10.2144/03351md01 (2003).

54. Tost, J., Dunker, J. \& Gut, I. G. Analysis and quantification of multiple methylation variable positions in CpG islands by pyrosequencing. Biotechniques 35, 152-156. https://doi.org/10.2144/03351md02 (2003).

55. Blaine, S. K. \& Sinha, R. Alcohol, stress, and glucocorticoids: From risk to dependence and relapse in alcohol use disorders. Neuropharmacology 122, 136-147. https://doi.org/10.1016/j.neuropharm.2017.01.037 (2017). 
56. Richardson, H. N., Lee, S. Y., O’Dell, L. E., Koob, G. F. \& Rivier, C. L. Alcohol self-administration acutely stimulates the hypothalamic-pituitary-adrenal axis, but alcohol dependence leads to a dampened neuroendocrine state. Eur. J. Neurosci. 28(8), 1641-1653. https://doi.org/10.1111/j.1460-9568.2008.06455.x (2008).

57. Efstathopoulos, P. et al. NR3C1 hypermethylation in depressed and bullied adolescents. Transl. Psychiatry 8, 121. https://doi.org/ 10.1038/s41398-018-0169-8 (2018).

58. Braithwaite, E. C., Kundakovic, M., Ramchandani, P. G., Murphy, S. E. \& Champagne, F. A. Maternal prenatal depressive symptoms predict infant NR3C1 1F and BDNF IV DNA methylation. Epigenetics 10, 408-417. https://doi.org/10.1080/15592294.2015.10392 21 (2015).

59. Song, Y. et al. Altered DNA methylation status of human brain derived neurotrophis factor gene could be useful as biomarker of depression. Am. J. Med. Genet. Part B Neuropsychiatr. Genet. 165B, 357-364. https://doi.org/10.1002/ajmg.b.32238 (2014).

60. Hompes, T. et al. Investigating the influence of maternal cortisol and emotional state during pregnancy on the DNA methylation status of the glucocorticoid receptor gene (NR3C1) promoter region in cord blood. J. Psychiatr. Res. 47, 880-891. https://doi.org/ 10.1016/j.jpsychires.2013.03.009 (2013).

61. Jackson, S. E. \& Steptoe, A. Obesity, perceived weight discrimination, and hair cortisol: A population-based study. Psychoneuroendocrinology 98, 67-73. https://doi.org/10.1016/j.psyneuen.2018.08.018 (2018).

62. Milagro, F. I., Mansego, M. L., De Miguel, C. \& Martinez, J. A. Dietary factors, epigenetic modifications and obesity outcomes: Progresses and perspectives. Mol. Aspects Med. 34, 782-812. https://doi.org/10.1016/j.mam.2012.06.010 (2013).

63. Freitas, F. V. et al. Psychosocial stress and central adiposity: A Brazilian study with a representative sample of the public health system users. PLoS One 13, e0197699. https://doi.org/10.1371/journal.pone.0197699 (2018).

\section{Acknowledgements}

We thank the volunteers who participated in this study, Community Health Agents, and the entire team of the Public Unified Health System of the Municipality of Alegre, ES, Brazil, Fundação de Apoio à Pesquisa do Espírito Santo (FAPES, SUS Research Project PPSUS) and Conselho Nacional de Desenvolvimento Científico e Tecnológico (CNPq grant number 424130/2018-1) for funding. We also would like to thank Editage (www.editage.com) for English language editing.

\section{Author contributions}

J.A.P. and A.M.A.S. conceived and designed of the study. F.V.F., A.R.B., C.L.C., J.K.A., T.S.V., R.A.S., D.P.S., W.M.B., A.B.A., E.B.B. collected sample and all data. J.K.A., M.M.O, J.G.S., B.P.S., L.M.R.B.A. performed molecular analysis. F.V.F., A.R.B., S.O.M., C.L.C., L.O.T., L.M.R.B.A. assisted with data analysis and interpretation of findings. S.O.M., J.C.C.R., L.O.T, I.D.L. performed a critical review of the manuscript. And J.A.P, L.M.R.B.A., A.M.A.S. drafted the manuscript. All authors critically reviewed content and approved final version for publication.

\section{Funding}

This work was carried out with the support of the Higher Education Personnel Improvement Coordination-Brazil (CAPES)-Financing Code 001.

\section{Competing interests}

The authors declare no competing interests.

\section{Additional information}

Correspondence and requests for materials should be addressed to A.M.A.-d.

Reprints and permissions information is available at www.nature.com/reprints.

Publisher's note Springer Nature remains neutral with regard to jurisdictional claims in published maps and institutional affiliations.

\footnotetext{
(c) (i) Open Access This article is licensed under a Creative Commons Attribution 4.0 International License, which permits use, sharing, adaptation, distribution and reproduction in any medium or format, as long as you give appropriate credit to the original author(s) and the source, provide a link to the Creative Commons licence, and indicate if changes were made. The images or other third party material in this article are included in the article's Creative Commons licence, unless indicated otherwise in a credit line to the material. If material is not included in the article's Creative Commons licence and your intended use is not permitted by statutory regulation or exceeds the permitted use, you will need to obtain permission directly from the copyright holder. To view a copy of this licence, visit http://creativecommons.org/licenses/by/4.0/.
}

(c) The Author(s) 2021 